\title{
Assessment of the Role of Research in Molding Cooperative Policies
}

\author{
Desalegn Fekadu Etefa, PhD Candidate, ID.NO: DRC/0002/2011 \\ Ambo University: Institute of Cooperatives and Development Studies, Department of Cooperative \\ Studies
}

\begin{abstract}
A cooperative society is an autonomous association of persons who have united voluntarily to meet their common economic, social and cultural needs and aspirations through a jointly owned and democratically controlled organization, making equitable contributions to the capital required and accepting a fair share of the risks and benefits of the duty. Its role to economic development in developed, developing and under developed countries is very immense. Cooperation among people has existed since history has been record. However, the history of formal cooperatives in Ethiopia dates back to 1960, when the first directive of cooperatives was enacted. The review article is prepared with the main objective of assessing the role of research in molding the cooperatives policies. To do so, an appropriate methodology employed was descriptive research design. The source of data used is secondary data from the literature review and articles of different materials. The instruments used for data collection is review of compiled documents. The study shows that cooperatives are contributing to the socio-economic development of the country. Due to the enabling environment created by proclamation No. 147/ 1998, the numbers of primary cooperatives started to increase from 10,524 to 56,044 and members simultaneously increased from 4,529,259 to 9,165,267 having capital 8.8 billion birr. However, the degree of participation of the people and other stakeholders in policy making process is low. The finding identified major issues among which less room of participation of the concerned bodies in the policy formulation process, lack of clear demarcation of how to exercise power on government structures, lack of clear operational areas; lack of strong governance, lack of national federation, weak linkage between cooperatives and Universities; above all lack of fully implementing researchers' recommendation. Thus, it seems to be imperative to fully implement the research findings and taking corrective measures to solve the challenges of the sector so as to gain an anticipated outcome.
\end{abstract}

Keywords: key words, Cooperatives; Policy; Contribution of research.

DOI: $10.7176 /$ PPAR/9-5-02

Publication date:May $31^{\text {st }} 2019$

\section{Introduction}

The concept of human cooperation is not new; it existed even before the formation of modern cooperation. To overcome their immediate problems and to share their feelings, human beings traditionally work together in day to day life. As it is defined by Gary, B. Hansen (1993), cooperative is an association of persons who have voluntarily joined together to achieve a common goal.

Evidence from various sources reveals that cooperatives are contributing great share to the country's economic and social development. For instance, report of International Cooperative Alliance (ICA) and International Labour Organization (ILO) (2014) stated that about one billion people are involved in cooperatives in some way, either as members/customers, as employees/participants, or both. As to the same report, cooperatives are believed to be source of employment at least to 100 million people worldwide. The livelihoods of nearly half of the world's population are secured by cooperative enterprises. This is particularly true in the rural areas where it provides an important potential for income generation and equity for the rural dwellers.

In order that cooperatives play their role, government support is highly needed. Government support cooperatives in creating enabling environment. These include putting in place sound economic policy, technical, legal and administrative support to sector development, providing regulatory frameworks and transparent system; all of which together will create an environment conducive to sector development (United Nations Framework Convention on Climate Change (UNFCCC), 2014).

As modern business structure, cooperatives originated in Britain by Robert Owen in 1844 and it was introduced in Ethiopia in 1960 during imperial Hailesillasie regime. Successive governments, starting from the Imperial period to the Ethiopian People's Revolutionary Democratic Front (EPRDF), gave due attention to the role of coops and made deliberate effort to promote the same. However, the principles and approaches followed were obviously different, reflecting the political thinking and ideology of the regimes.

As indicated in the work of Kifle Tesfamariam (2015), the present government provided a legal framework which incorporates universally accepted principles of cooperatives (Proclamation No. 147/1998 and 402/2004). As a result of these; many cooperatives have been established in new forms in Ethiopia since 1998 following the initiatives taken by the government. 
For cooperatives principles to be fully implemented there should be efficient policies to guide it. However, the process of policymaking in the country lacks the fundamental elements of the activities. Furthermore, the policy making in Ethiopia is not following a systematic and consultative procedure rather it is top down approach while a genuine bottom-up policy process is possible and preferable making (A. Teshome, 2007, cited in Kemal A. Kaso, 2018).

Moreover, to treat the unique features of cooperatives that enable to compute with the dynamic world, linking cooperatives with research centers has paramount importance. This indicates the role of research in achieving sustainable growth and social transformation of countries is indisputable. The main purpose of research is to inform action, to prove a theory, and contribute to developing knowledge in a field or study. For that matter, Universities are central institutions in contemporary knowledge economy that generate knowledge, innovative thinking and a skilled workforce. They play a critical role in training professionals and researchers and in generating new knowledge to support national innovation systems. The findings can only be used as an input if researchers and policy makers cooperate closely to understand each other.

With this regard, there is no industrial relations between policy makers and researchers. Kemal A. Kaso (2018) indicated that there was less room of participation for the people and other stakeholders in the policy formulation process in Ethiopia.

In general, in spite of the problems noted, cooperatives are playing crucial role to the socio-economic development and also the policies are contributing for the sector's performance. Had the top authorities closely worked with the concerned institutions particularly with the researchers and scholars, entirely implementing the findings and recommendations given; the result would have been by far more. Consequently in line with these realities, in this article review, the role of research in molding cooperatives policies, the gaps identified by scholars and what corrective measures should be in place for the sector to play its role are the area of concern in this review article.

\section{General objective}

To assess the role of research in molding the cooperative policy in Ethiopia

Specific Objectives

1. To assess the role of cooperatives in Ethiopia

2. To examine the importance of policy for cooperatives

3. To identify the role of research in cooperative policy

4. To show an intervening strategies for policy makers and other researchers

\section{Methodology}

For the purpose of writing this article, the data has been collected from various secondary sources Thus, the article review is based on secondary data obtained from different scholars and authors; review of relevant literature on cooperatives, policy and regulatory framework documents, past study reports and cooperatives periodic activity reports as cited in some authors. In addition, some important documents like Federal Cooperative Proclamation No 147/1998, Cooperative Societies (Amendment) Proclamation No 402/2004 and Council of Ministers Regulation were reviewed.

\section{Concept of Cooperatives, Historical Development and Cooperatives' Policy 3.1 Concept of Cooperatives}

A cooperative is a non-profit based service organization owned and operated by its members. In many ways it is like any other business, but in several important ways it is unique and different. It has been the very basis of human civilization. The inter-dependent and the mutual help among human beings have been the basis of social life. It is the lesson of universal social history that man cannot live by himself and for himself alone. Since the beginning of human society, individuals have found advantage in working together and helping one another in all over the world. A cooperative operates for the benefit of its members. These member-owners share equally in the control of their cooperative. The members elect directors which, in turn, hire management to manage the day-to-day affairs of the cooperative in a way that serves the members' interests. It is based on the idea people working together for a common goal and common good (Ahmad, D. B., 2005).

This indicates cooperatives as economic enterprises and as self-help organizations, play a meaningful role in uplifting the socio-economic conditions of their members and their local communities. With their concern for their members and communities, they represent a model of economic enterprise that places high regard for democratic and human values and respect for the environment.

As in any other institution, having legal entity is found very vital in cooperatives. Hence, as to UNFCCC (2014), government's supports are manifested in the form of creating conducive environment, which includes eliminating technical, legal and administrative barriers, putting in place sound economic policy, regulatory frameworks and transparent system, all of which together will create an environment conducive to sector development. 
Historically, early state had tasks at its disposal very minimal in extent. Its role originally was almost entirely political and geared at the maintenance of internal peace and security and protection from external aggression. The early state did use to carry out trade and engage in economic activities but only to a limited extent-merely to finance itself and accumulate wealth to cover its administrative expenses. Moreover, small commercial undertakings were run by administrative departments that constitute the state itself. This shows that commerce was a field of action for a state only incidentally because the administrative departments undertake commercial activities as secondary and subservient duties to their normal tasks of public administration.

But with the proliferation of tasks expecting state accomplishment accompanied by expansion of economic concepts and accordingly with the emergence of a modern state, i.e., welfare state or activist state, such old functions had to be radically changed. The activities of the modern state have become diverse and multifarious, and thus administrative departments are no more capable of simultaneously discharging administrative functions and economic activities. The role of the state in the economy has greatly increased so that it has to ensure economic growth of a country and provide welfare services to its citizens. In short, the function of the state has become the adoption of a policy which would secure distribution of ownership and control of material resources of the society to serve the common good and which ensures the operation of the economic system does not result in the concentration of wealth and means of production to the detriment of this common good (Addissie Shiferaw and Dagnachew Asrat, 2009).

In connection to the cooperatives development, an immense role of government is expected in line to the special features of the sector. Thus, governmental authority of a state cannot only impose a certain economic direction but also can influence and shape the legal structure to operate in the context of the proclaimed economic system.

As modern business structure, it was in $19^{\text {th }}$ century in Britain that cooperatives originated (Evans Lewis, 2006). The Industrial Revolution had a profound effect on the way business was organized and on the working conditions and economic situations of many people there. In response to the depressed economic conditions brought forth by industrialization, some people began to form cooperative businesses to meet their needs. Among them was a group of 28 workers who were dissatisfied with the merchants in their community. They formed the first consumer cooperative known as the Rochdale Society of Equitable Pioneers in 1844 in Rochdale England (Birchall, 1997). They began by opening a cooperative store that sold items such as flour and sugar to members, and the society quickly grew to include other enterprises. The founders also established a unique combination of written policies that governed the affairs of the cooperative. Among these rules were: democratic control of members, payment of limited interest on capital, and net margins distributed to members according to level of patronage. Based on its success, the Rochdale set of policies soon became a model for other cooperative endeavors, and became known as the general principles that make a cooperative unique from other business structures.

\subsection{History of Modern Cooperatives and Cooperative Policies in Ethiopia}

\subsubsection{Cooperatives during the Imperial Regime (Before 1974)}

Modern cooperatives movement started very recently in Ethiopia as envisaged by Decree No. 44 of 1960 though it did not get legal status until 1978. It is with the promulgation of this Decree (Farm workers' Decree) that cooperatives have come to acquire their formal legal status. Although cooperatives have acquired their formal legal status since the promulgation of this decree, it was not until 1978 with the adoption of the cooperative society's proclamation No. 138 of 1978 that their status is realized in line with their objectives.

In its Five Year Development Plan, the Imperial regime envisaged an important role for coops in transforming smallholding agriculture. Thus, the Farmer Workers Cooperative Decree No. 44 is provided the first legal framework, which was later replaced by the Cooperative Societies Proclamation No. 241/1966. This was relatively comprehensive and contained most of the essential contents of the legal framework issued more than three decades later in 1998 and coops were rightly viewed as primarily voluntary undertakings. However, success was limited during the period (Kifle Tesfamariam, 2015).

\subsubsection{Cooperatives in the Military Regime (1974-1991)}

The 1975 proclamation that provides for nationalization of rural land and extra houses in urban areas on its article 10 provided for the creation of marketing and credit cooperatives by peasant association. The intention of the Military regime was to use coops as a key instrument to build a socialist economy. Thus, it pursued the cooperatives agenda more aggressively. The cooperatives were not autonomous organizations, but had purely political character. The approach followed combined coercion with extensive support including priority access to resources, goods and services. Whereas number of coops and membership size were relatively large, it is not regarded as a particular success for a number of reasons. Coops were so unpopular that following the decease of the Derg regime in 1992 most of them disappeared quickly. The number of primary cooperatives reached 10, 524 having 4,529,259 members started to decrease following the downfall of the Derge regime. What is worse is that they dissolved in such a disorderly manner (e.g. bank loans and other obligations were not settled; no distribution 
of assets between members; etc.) that it created a lasting suspicion and distrust of cooperatives the stigma of which is haunting cooperatives until today.

In general, cooperatives in the Derge regime were characterized by corruption and mismanagement, and served as a vehicle for the government mass collectivization policy as well as a forced recruiting ground for fighting for Mengistu's escalating internal conflicts (McCarthy, 2001).

\subsubsection{Cooperatives under the Present Government (Since 1991)}

The present government provided a new legal framework (Proclamation No. 147/1998 and 402/2004) to promote cooperatives. It was comprehensive and incorporated universally accepted principles of cooperatives. As a result some improvements have been seen in cooperative societies in the country. In the history of cooperative movement in Ethiopia, the government has taken serious measures after 1996. The measures include, organizing and reorganizing different types of agricultural cooperatives and establishing Cooperative Promotion Bureaus in regions. At the Federal structure, the government has been established the cooperative promotion desk under the Prime Minister office. A proclamation No. 147/ 1998 to provide for the establishment of cooperative societies had also declared by the Federal Government to bring all types of cooperative societies under one umbrella. The Federal Cooperative Commission (currently Federal Cooperative Agency) based on proclamation No. 274 / 2002 was established in 2002. Moreover, to correct the short comings in the proclamation 147/1998 and amendment $402 / 2004$ and regulation number 106/2002 became an important contributory document in the cooperative movement of the country (Addissie Shiferaw and Dagnachew Asrat, 2009).

However, in Ethiopia, in the policy formulation process, few government officials on the top are the key actors whereas the people and other stakeholders have limited participation in the process. In this regard, the study conducted by Alemu, T. (2015), for the process of policymaking the responsible bodies are not only politicians, but also representatives of the people, experts and scholars. Moreover, the finding Kemal A. Kaso (2018) show that most policies that guide the existing system are emanating from executive particularly, the Prime Minister. And there is limited legislative branch role, and other policy actors at both federal and regional levels.

In spite of the defects mentioned so far, cooperatives became a path to socio-economic and social empowerment in Ethiopia since 1991. As of May 2014, according to the Federal Cooperative Agency (FCA), there were 311 cooperative unions, with 56,044 primary cooperatives operating in all regional states of Ethiopia with the aggregate membership size of 9,165,267 (6,949,589 males and 2,215,678 females) having capital amounting to 8.8 billion birr. The regional distribution of primary cooperatives shows that Oromia $44 \%$, Amhara 21\%, SNNP 17\%, Tigrai 10\% and Addis Ababa 5\%. The remaining five regions (Somalia, Afar, Gambella, Beneshangul and Harare) and Dire Dawa city collectively accounted for $3 \%$ of the number of cooperatives in the country (FCA, 2014).

\subsection{Challenges of Cooperatives}

In spite of the some progress mentioned above, cooperative movement during the last 50 years of its existence is not inspiring. Empirical evidence reveals that the cooperative movement in Ethiopia is facing several challenges. This sector is reliant on government for various reasons. There are also continuous government interferences, governance issues, accountability, legislative and policy support and new product development. The major challenges are the following:

Lack of Awareness: This is the most major problem of cooperatives in Ethiopia. People are not well informed about the objective of the movement, the contributions it can make in rebuilding the society and the rules and regulations of cooperative institutions. People look upon these institutions as means for obtaining facilities and concessions from the government. This hinders the application of cooperative principle 'democratic member control'.

\section{Lack of Professionalism}

This is related to the cooperatives' management committee members who have no knowledge of cooperative business transaction. In most cases cooperatives are unable to employ capable management staff and the burden of due diligence is left to cooperative members who may have limited education on financial management. These committee members lack essential capability to exercise good governance.

\section{Inadequate Support and Weak Regulation and Supervision}

The capacity of FCA and regional cooperative promotion agency to effectively promote, regulate and supervise cooperatives is not in a position. This is resulted from absence of separate specialized units at the federal, regional and woreda levels in charge of promoting, supervising and regulating different type of cooperatives; and limited mobility of staff due to shortage of logistics.

Accountability of the Federal Cooperative Agency (FCA) and Regional Offices

The is accountable to the Ministry of Trade which has no much concern with cooperatives and Regional Cooperative Agencies are accountable to the Agricultural Offices. Due to this, there is lack of strong coordination to solve the problems of cooperatives. 


\section{Interpretational Dissimilarities of the Cooperative Legislation at Various Levels}

The boundary of exercising power between the federal and the regional states lack clarity. The formation of cooperative federation would be a typical example. According to the FCA strategic plan, the country follows four tier vertical structures: primary, union, federation and league. In practice some regions like SNNPR and Tigrai regions have establishing federation at regional level backed by the irrespective regional level cooperatives law. If cooperatives continue to integrate vertically, the federations established at regional levels are expected to form another layer before joining the league or the league will be established including the regional level federations. It is believed that such misunderstanding emanated from misinterpretation of the grand federal cooperative law and such confusions need to be cleared.

\section{Lack of Clarity about Operational Areas}

The operational area of cooperative societies established at different levels would be based on their economic benefits. The federal cooperative law proclamation No.147/1998, amendment No.402/2004 and regional states cooperative proclamations and cooperative agency do not define operational areas. This shows they perform their activities only at limited areas. In this way the cooperatives lack chance of expansion area and the communities lack services from cooperatives.

\section{Weak Linkage of Cooperative Sectors with Stakeholders}

There is no strong relation between FCA and different stakeholders, particularly with the research institutes. Learning and improvement in technical capability does not take place in isolation but in interaction with support institutions. There is need for policy-maker and policy analysts in Ethiopia to think more to relate their policies into the wider national system (United Nation, 2002). Practical evidence shows that the federal and regional governments' power relation, the absence of institutionalization and coordination are among the challenges that have impact on the integrated regional development policy formulation and even implementation (Kemal A. Kaso (2018). As to Oqubay A. (2015), some policy instruments were not entirely based on research.

\section{Low Stakeholders' Participation}

There was less room of participation for the people and other stakeholders in the policy formulation process in Ethiopia (Kemal A. Kaso (2018). Most people knew nothing about the processes involved in formulating policies; only those who had participated in the process as committee members or by attending workshops seemed to have an idea of what was involved (Worku Tessema, 2000).

The political roles and ideology of the ruling party shaped the policymaking process, in which its ideas and interests prevailed and intertwined with the policies and structures of government both at federal and regional levels. In principle, however, in the process of policymaking the responsible bodies are not only politicians, but also representatives of the people, experts and scholars, especially in today's 'administrative state' era, with the rapid expansion of government functions and the extensive use of administrative discretion, administrative authorities are involved in public policy initiative growing (as cited in Huang, R., 2002).

\section{Conclusion and Recommendations}

\subsection{Conclusion}

Cooperatives play a major role in socio-economic development. Cooperatives are also seen as vehicles for the injection of government development strategies to the local level. In Ethiopia, it started to function as a modern economic sector since 1960. For it to accomplish its goal; the successive regimes tried to create an enabling condition. However, the principles and approaches followed were different, reflecting the political thinking and ideology of the regimes. As a result of a Policy support, especially the favorable condition created by proclamation No. 147/ 1998, the numbers of primary cooperatives started to increase from 10,524 to 56,044 and members simultaneously increased from 4,529,259 to $9,165,267$ having capital amounting to 8.8 billion birr. However, there is lack of clear demarcation of how to exercise power on government structure.

In spite of the some progress mentioned above, cooperative movement during the last 50 years of its existence is not inspiring. There are problems identified within and out of the cooperatives, which needs the contribution of the concerned bodies to solve the problems.

\subsection{Recommendations}

Based on literatures reviewed, actions that can be taken by governments at different levels to strengthen cooperatives and for the sector growth in general are identified. Accordingly, the major solutions that should be undertaken are stated below: -

\section{Providing Cooperatives Education and Training}

Most of the cooperative members are having lack of awareness on cooperative activities, legal aspects, and cooperative business. Assistance is therefore required in investing in training programs that create awareness to the cooperative members on their rights. This would in turn make them demand for good governance, transparency and accountability. Therefore, there is a need to strengthen the cooperative training institutions to undertake demand based training programs and continue cooperative education to cooperative members, 
managers and other concerned officials. In addition to this, trainings and education will be designed transmitted thorough the government media and formal educational programs.

\section{Solving Capital and Infrastructural Problems of Cooperatives}

As obviously known, the main capital source of cooperatives is member's share capital. However, the current situation clearly shows that cooperative is not in a position to collect sufficient capital from their members. This is mainly due to low capital base and low income of members. Moreover, cooperatives are not in a position to get a credit from financial institutions due to collateral problems. Hence a financial capacity building system should be designed in a short period of time. Some of the majors to be undertaken are establishment of national cooperative bank to combat the problems of finance like the experience in the case of Kenya. Moreover, the rural development policy should incorporate cooperatives' storage and infrastructure to improve cooperatives involvement in the rural development programs.

\section{Attracting Professionals}

As various research shows at different tiers of cooperative structure, the sector lacks appropriate leaders. In most cases cooperatives are led by management staff and the burden of due diligence is left to cooperative members who may have limited education on financial management. On the one way, this sector lacks professionals and on the other way there is frequent turnover. Thus, to sustain this sector, creating conducive environment is very important.

\section{Providing Enabling Legislation and Regulation}

For cooperatives to function appropriately; there is a need of creating an enabling work environment. Thus, laws governing cooperatives should be constantly revised to go with changes. It was in 1998 that the first proclamation was enacted and revised 18 years later in 2016. There were so many changes and hence so many problems cooperatives were facing in between these intervals.

In general, governments should ensure a legislative and policy environment that permits cooperatives to be competitive by facilitating cooperative ability to purchase subsidiary businesses, enter joint ventures, trade and invest across national boundaries and amalgamate or otherwise merge their activities in whole or part with other cooperatives.

\section{Creating Strong Linkage Between Cooperatives and Others}

To fill the gaps existing in this sector, there should be a strong linkage between governing sector and others particularly with Universities existing in the country. The FCA should collaboratively work together with the research institutes to enable coop competitive enough.

\section{Implementing the Research Findings}

Some of the overlapping mandates identified should be solved by FCA. Cooperative structure at all levels lack professionals. There are also frequent turnover in the sector. Operational areas of cooperatives is not clearly defined, which needs the authorities to design means of defining and at the same time, means of supporting cooperatives at conditions of financial risks. The functionality of the fourth tier of cooperative should be set and there should be uniformity among regions and should also be backed by regional laws. At national level, the country should also have national federation, which is missed in our case and there should be separate ministry for cooperative to give uniform leadership.

To sum up, Cooperatives sectors are contributing to the country's socio-economic development. The government is also working to create conducive environments by providing policies and legal systems, though the progress is not comparable with the existing potentials. Hence, to shift the identified problems, strong commitment is required from the concerned bodies. Among these, involvements of all stakeholders particularly of the intellectuals and incorporation of the research findings to bring dramatic change should get paramount importance. Moreover, to increase the effectiveness and overall practice of policy formulation in Ethiopia, promoting good governance that creates peaceful co-existence, a sound political linkage and coordination among different governmental levels and administrative sectors in the country should get due consideration.

\section{Acknowledgements}

First and foremost, I would like to thank the Almighty God for this wonderful opportunity he has given me to write this review article. Secondly, I would like to extend my sincere thanks and gratitude to my Research Methodology Instructor Dr. Workneh Wodajo for orienting me well on how to prepare sound full thesis, journals and articles. By doing this assignment, I started to further apply what is delivered in the theoretical part. As a result, I have got a chance of looking at different articles already prepared. Thus, I thank him for giving this practical assignment where I gain experience and get prepared for the future any academic writings. Finally, I thank all writers of those materials I referred.

\section{References}

Addissie Shiferaw and Dagnachew Asrat (2009). Law of Public Enterprises and Cooperatives: Justice and Legal System Research Institute, Addis Ababa. 
Adeler, M. J. (2009). Enabling Policy Environments for Co-operative Development. Winnipeg: Institute of Urban Studies, University of Winnipeg.

Adugna, H. (2013). Co-operative Approach to Community Livelihood Improvement: The Case of Ada'a District, Oromia Regional State, Ethiopia, Published: International Journal of Development and Sustainability.ROLE

Ahmad, D. B. (2005). The Role of Cooperative Societies in Economic Development: published in the official journal of the Department of Public Administration, Ahmadu Bello University, Zaria-Nigeria.

Alemu. T. (2015). Policymaking Practice and Challenges of House of Peoples Representatives (HoPRs). Sky Journal of Agricultural Research, 4(7), 132-146.

Bezabih Emana (2009). Cooperative: a Path to Economic and Social Empowerment in Ethiopia. Coop AFRICA Working Paper No.9, ILO, Dare Salam, $\mathrm{pp}^{9-14}$.

Birchall, J. (1997). The international Co-operative Movement. Manchester, UK: Manchester University Press.

David J, (2008). Mobilizing Rural Institutions for Sustainable Livelihoods and Equitable Development; International Food Policy Research Institute Addis Ababa Ethiopia.

Ethiopian Academy of Sciences (2015). Re-envisioning Higher Education and Research in Ethiopia, Proceedings of the Second Science Congress, Addis Ababa.

Evans Lewis, M. R. (2006). The Role and Significance of Cooperatives in New Zealand Agriculture: A Comparative Institutional Analysis.

Federal Cooperative Agency (2009). Status of Cooperatives in Ethiopia: (Unpublished) Addis Ababa

Federal Cooperative Agency (FCA) (2010). Cooperative Annual Magazine: Addis Ababa, Ethiopia.

Federal Cooperative Agency (2014). Federal cooperatives Agency, Annual Publication, Vol1, No11

Gary B. Hansen (ILO COOP) (1993). The role of Cooperatives in the Promotion of Employment and Income: Presentation of to the Meeting of Experts on Cooperatives, March 31, 1993 at the ILO in Geneva, Switzerland.

Huang, R. (2002). On the nature of public policy. Beijing: Peking University, Beijing Chinese Public Administration Review.

International Cooperative Alliance (ICA) and International Labor Organization (ILO) (2014). "Cooperatives and the Sustainable Development Goals: A Contribution to Post 2015 Development Debate." A Policy Brief, Geneva.

Kemal A. Kaso (2018). Integrated Regional Development Policy Formulation in Ethiopia, Journal of Politics and Law; Vol. 11, No. 4; 2018 ISSN 1913-9047 E-ISSN 1913-9055 Published by Canadian Center of Science and Education

Kenichi Ohno (2009). Ethiopia: Political Regime and Development Policies, Graduate Institute for Policy Studies (GRIPS), Tokyo.

Kifle Tesfamariam (2015). Cooperative Movement in Ethiopia: Development, Challenges and Proposed Intervention, Journal of Economics and Sustainable Development, Vol.6, No.5, Retrieved from www.iiste.org ISSN 2222-1700.

Laidlaw, A.F (1974). The Cooperative Sector, Columbia: University of Missouri, USA, $\mathrm{pp}^{6-8}$.

McCarthy (2001). "The History of Agricultural Cooperatives" in Cooperative Business Today. First Quarter Vol.1 Issue 1, VOCA- Addis Ababa, Ethiopia.

Ministry of Finance and Economic Development (Mo FED), (2005). Sustainable Development

Ministry of Finance and Economic Development. (2010). Growth and Transformation Plan (GTP), 2010/112014/15. Addis Ababa, Ethiopia.

N. Mohammed, (2015). Role of Cooperatives in Rural Development, the Case of South Nations Nationalities and People Region, Ethiopia Science Journal of Business and Management: volume 3.

Oqubay A. (2018). Industrial Policy and Late Industrialization in Ethiopia, Working Paper Series $\mathrm{N}^{\circ} 303$, African Development Bank, Abidjan, Côte d'Ivoire, African Development Bank

Wendy Laura Belcher (2009). Writing your Journal Article in 12 Weeks: A Guide to Academic Publishing Success, USA, SAGE Publications, ISBN: 978-1-4129-5701-4.

Worku Tessema (2000). Stakeholder participation in policy processes in Ethiopia, Managing Africa's Soils No. 17, IIED publications, London.

United Nations Framework Convention on Climate Change (UNFCCC) (2014, January 23). An Integrated Environmental Treaty, Retrieved from http://unfccc.int/2860.php

United Nation (2002). Investment and Innovation Policy Review in Ethiopia, United Nations Conference on Trade and Development, Geneva.

Yoseph Derese (2014). Government Support Interventions and Autonomy of Agricultural Cooperatives in Ethiopia: The Case of Selected Regions, MA Thesis, Addis Ababa University. 